\title{
La Houille Blanche
}

\section{Adaptation of coastal structures to mean sea level rise}

Philippe Sergent, Guirec Prevot, Giovanni Mattarolo, Jérôme Brossard, Gilles Morel, Fatou Mar, Michel Benoit, François Ropert, Xavier Kergadallan, JeanJacques Trichet \& Pascal Mallet

To cite this article: Philippe Sergent, Guirec Prevot, Giovanni Mattarolo, Jérôme Brossard, Gilles Morel, Fatou Mar, Michel Benoit, François Ropert, Xavier Kergadallan, Jean-Jacques Trichet \& Pascal Mallet (2014) Adaptation of coastal structures to mean sea level rise, La Houille Blanche, 100:6, 54-61, DOI: $10.1051 / \mathrm{hb} / 2014063$

To link to this article: https://doi.org/10.1051//hb/2014063

๑) Société Hydrotechnique de France, 2014 Published online: 21 Jan 2015.

Submit your article to this journal $\sqsubset$

Џll Article views: 2

Q View related articles $\sqsubset$

View Crossmark data \lceil

4

Citing articles: 2 View citing articles $\square$ 


\title{
Adaptation of coastal structures to mean sea level rise
}

\author{
Philippe SERGENT ${ }^{1}$, Guirec PREVOT ${ }^{1}$, Giovanni MATTAROLO², Jérôme BROSSARD ${ }^{3}$, \\ Gilles MOREL ${ }^{4}$, Fatou MAR ${ }^{4,5}$, Michel BENOIT ${ }^{2}$, François ROPERT 6 , Xavier KERGADALLAN ${ }^{1}$, \\ Jean-Jacques TRICHET ${ }^{1}$, Pascal MALLET ${ }^{7}$
}

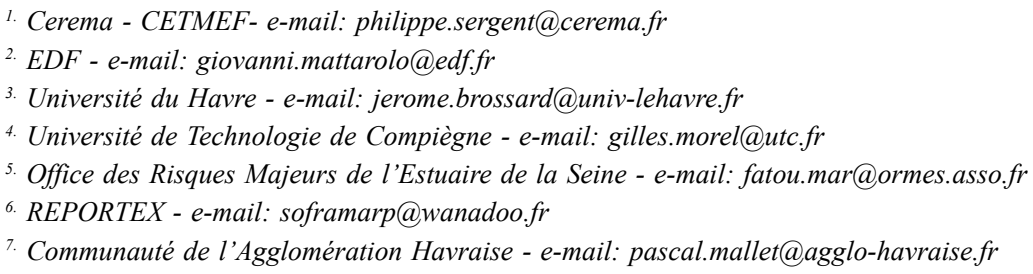

ABSTRACT. - With the mean sea level (MSL) rise, coastal defence structures will be exposed to wave height, which are larger than the design values, in particular for all the structures built in shallow waters where the depth imposes the maximal wave height due to bathymetric breaking. If MSL rise is one meter, the crest of these structures will have to be raised between two and three meters in order to keep the same overtopping volumes. Moreover the structures will have more severe damages and mass of armour units should be doubled. Statistics moderate the first conclusions because it keeps into account the whole set of events, including in particular shoaling waves. Schematically with the increase of damages, according to the severity of changes the stakeholders will adopt one of the following scenarios: a) repairing the structures as it is b) reinforcing the structures c) demolishing and redesigning the structures d) accepting coastal realignment. Three axes of reinforcement of structures are presented: limiting overtopping by modifying for example the crown wall, improving armour stability by adding an armour layer or by using milder armour slope and reducing the incident wave energy by building a detached low-crested breakwater or by sand nourishment. A curved parapet wall is a very efficient solution for impervious structures. This solution must often be completed by an additional armour layer for pervious structures. The front reservoir is also a promising solution. Cost benefice analysis (CBA) applied to the city of Le Havre shows that reinforcement becomes economically justified in district of Malraux when MSL rise is $1 \mathrm{~m}$. Redesign and coastal realignment as far as they are concerned are acceptable when MSL rise exceeds $2 \mathrm{~m}$.

Key-words: climate change, adaptation, mean sea level rise, coastal structure, design

\section{Adaptation des structures côtières à la montée du niveau marin}

RÉSUMÉ. - Avec la remontée du niveau marin (NM), les digues côtières seront exposées à des vagues dont la hauteur sera plus grande que la valeur de dimensionnement, notamment toutes les structures construites en faibles profondeurs où la profondeur impose l'amplitude maximale à cause du déferlement bathymétrique. Si une hausse d'un mètre du NM doit se produire, ces ouvrages devront être rehaussés en première approche de deux à trois mètres pour conserver la même performance en termes de franchissement. En outre, ils subiront une augmentation des dommages non négligeables et la masse des blocs de la carapace devra souvent être doublée. L'approche statistique modère les premières conclusions car elle considère l'ensemble des évènements y compris les évènements en situation de shoaling. Schématiquement, avec l'augmentation progressive des dommages, le gestionnaire adoptera un des scénarios suivants selon la sévérité des changements : a) réparer l'ouvrage à l'identique b) renforcer l'ouvrage c) le démolir et changer les dimensions de l'ouvrage d) lancer un repli stratégique. Trois axes se dégagent pour renforcer les structures : limiter le franchissement (par exemple en modifiant le mur de couronnement), améliorer la stabilité de la carapace (en ajoutant une couche d'enrochements supplémentaire ou en adoucissant la pente) et réduire les sollicitations extérieures i.e. la houle (en implantant un ouvrage détaché ou en assurant un rechargement de sable). Il s'avère que l'ajout d'un becquet est une solution très efficace pour les ouvrages imperméables. Cette solution doit souvent être complétée par une couche supplémentaire d'enrochements pour les ouvrages perméables. Le bassin de déversement est aussi une solution prometteuse. L'approche coût bénéfice appliquée à la ville du Havre a montré que la solution du renforcement ne deviendra économiquement justifiée sur le quartier Malraux que si la montée du NM atteint $1 \mathrm{~m}$. Le redimensionnement ou le repli stratégique quant à eux ne peuvent être envisagés que pour des niveaux plus importants (au-delà de $2 \mathrm{~m}$ ).

Mots-clés : changement climatique, adaptation, niveau marin, structure côtière, dimensionnement 


\section{INTRODUCTION}

Impact of climate changes on coastal structures was studied within the framework of Discobole project [Lebreton, Trmal, 2009]. The methods that are used presently for structures design do not however enable to estimate correctly the consequences of climate change for three main reasons:

- The design is not based on statistics, single approach managing the complexity of coastal hazards;

- The design rules are generally proposed for new structures and consider badly the strengthening of former structures;

- The structure is generally considered alone and not in a system of dangers including several scales (the scale of the structure, the scale of the zone directly protected by the work, the scale of the zone impacted by the flood risk).

The SAO POLO project [Sergent, 2012] aims at answering to these three problems. This project uses:

- Analytical and statistical methods to estimate the impacts of climate changes in terms of overtopping and stability of coastal structures located in the breaking zone with a regular bathymetry and normal incident wave as well as the consequences on the updating of the design (strategy c);

- Laboratory tests in wave flume to study the reinforcement of three types of existing coastal structures (strategy b). - A study case in the district of Malraux in the city of Le Havre to establish a socioeconomic strategy for the choice among four strategies (a-b-c-d) presented in figure 1a.

Three axes of reinforcement of structures are possible: limiting overtopping by modifying the crown wall, improving armour stability by adding an armour layer or by using milder armour slope and reducing the incident wave energy by building a detached low-crested breakwater or by sand nourishment (see figure 1b).

\section{UPDATING OF THE DESIGN OF THE COASTAL WORKS}

An analytical study is led for a work located in the breaking zone. The change of the crest height $\Delta D$ between the final state with the MSL rise $\Delta h$ and the present state is obtained for low overtopping discharges (i.e. $\mathrm{q}<5 \cdot 10^{-2} \mathrm{~m}^{3} /$ $\mathrm{ml} / \mathrm{s}$ ). The ratio $\frac{\Delta D}{D h}$ always exceeds 1 and approaches 2 for pervious works and 3 for impervious structures.

Whatever are the offshore wave conditions, the works located in very shallow waters with a water depth between 0 and $2 \mathrm{~m}$ risk according to the calculations to undergo also very strong damages of their armour layers. The most concerned works are beach structures. Like the change of the crest height, the armour weight increases linearly with MSL rise.

A statistical method based on the Monte Carlo method and the joint probabilities of offshore wave heights and sea levels quoted relative to chart datum is then tested on the Deauville breakwater (see figure 2). This method requires at first a separate analysis of exceedance probability of offshore wave height at high tide (more precisely the maximal wave height between two successive high tides) and wind set-up at high tide (the difference between the maximal observed level and predicted level around high tide). Then the joint probability of offshore wave heights and of sea levels is found through a change of variables (transformation in centred normal distribution) in a normalized workspace (normal bivariate function). The sea level is the sum of tide and wind set up but the wave set up is not included because it is implicitly taken into account in the overtopping and stability formulae. A random sort finally supplies the database representing 10000 years of data at high tide (offshore wave heights and sea levels). The latter ones are then propagated and the overtopping discharges are determined by making vary the MSL. Two types of results are obtained: (a) the evolution of the return periods of overtopping discharges with the MSL rise; (b) the necessary raising of works to keep the same return periods for overtopping.

The results in terms of return periods for the Deauville breakwater are given in table 1 . The chosen overtopping discharge is strong $\left(5.10^{-2} \mathrm{~m}^{3} / \mathrm{s} / \mathrm{ml}\right)$. That is the overtopping level causing the wreck of the smallest ships at the back of the breakwater. A usual level of $1.10^{-5} \mathrm{~m}^{3} / \mathrm{s} / \mathrm{ml}$ represents a danger for pedestrians and vehicles. The present return
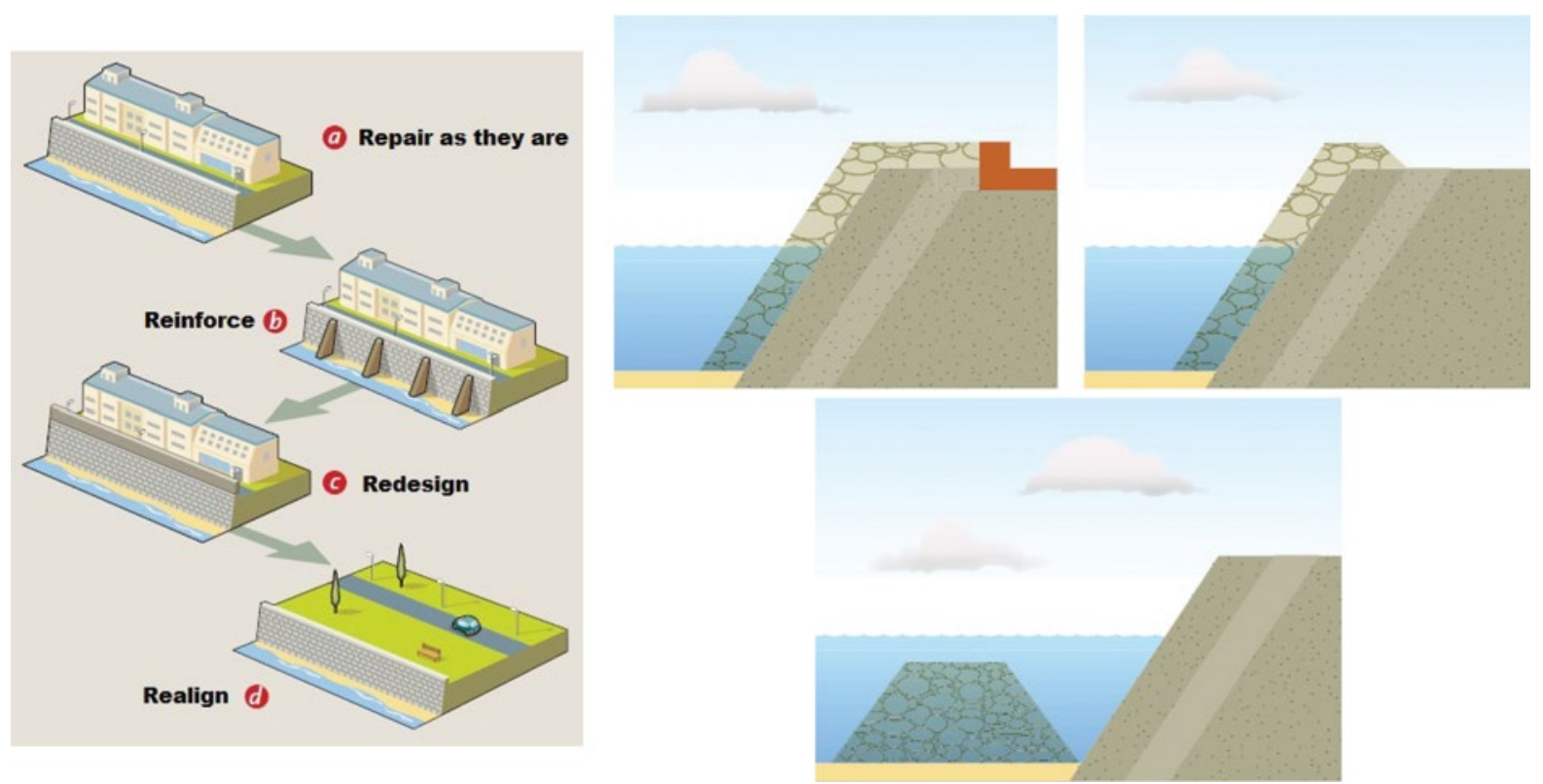

Figure 1 : Four strategies ( $a$ - left) and three options of reinforcement $(b-$ right). 


\section{BRISE LAMES}

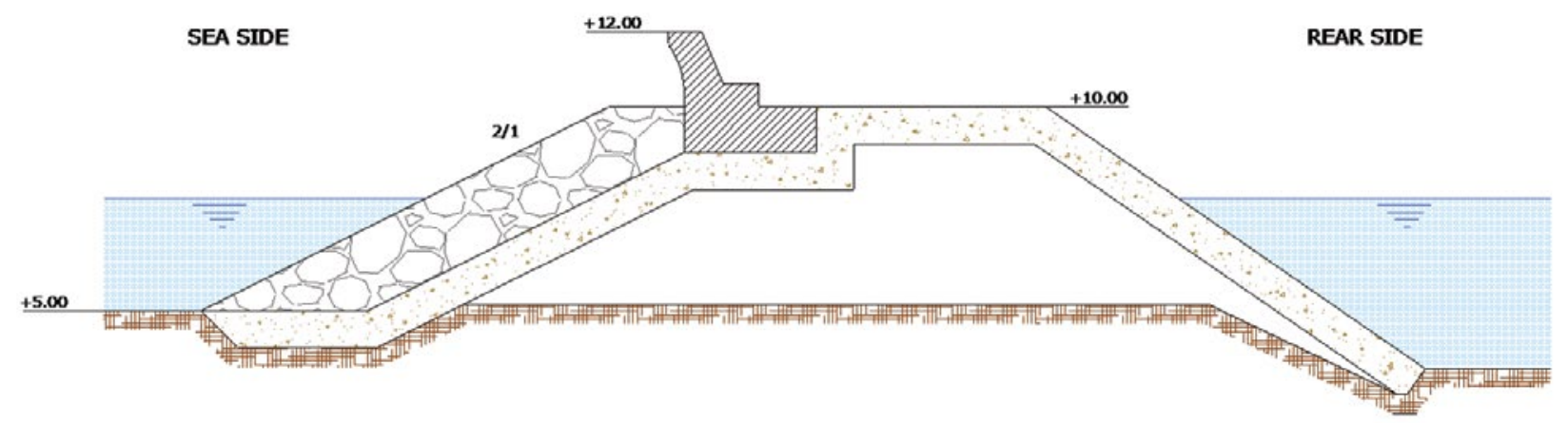

Figure 2 : Deauville breakwater.

Table 1 : Evolution of the return periods.

\begin{tabular}{|l|c|c|c|c|}
\hline MSL rise $(\mathrm{cm})$ & 0 & 40 & 60 & 100 \\
\hline Number of occurrences $\left(\mathrm{q}>5.10^{-2} \mathrm{~m}^{3} / \mathrm{s} / \mathrm{ml}\right)$ & 10 & 71 & 218 & 2437 \\
\hline Return period (years) & 1000 & 141 & 46 & 4 \\
\hline
\end{tabular}

Table 2 : Raise of the crest height.

\begin{tabular}{|l|l|l|l|l|}
\hline MSL rise $(\mathrm{cm})$ & 0 & 40 & 60 & 100 \\
\hline Raise of the crest height $(\mathrm{cm})$ & 0 & 57 & 85 & 140 \\
\hline
\end{tabular}

period is important (10 000 years). The big value of the initial return period implies a fast variation of this value with MSL rise. The results in terms of the raise of the crest height are gathered in table 2. For pervious rubble mound breakwaters the analytical study shows that, for $1 \mathrm{~m}$ MSL rise, the necessary raise of the crest height is equal to $1.74 \mathrm{~m}$ for an overtopping discharge of $5.10^{-2} \mathrm{~m}^{3} / \mathrm{s} / \mathrm{ml}$. The results of the statistical study moderate these results because the planned raising of the crest height is $1.40 \mathrm{~m}$. The analytical and statistical studies give results with significant differences because all of the wave conditions (breaking and shoaling) are taken into account in the statistical study whereas the analytical study includes only breaking waves. If only shoaling waves are taken into account, the necessary raise of the crest height is equal approximately to the MSL rise i.e. $1 \mathrm{~m}$.

\section{JOINT PROBABILITY METHOD}

According to Hawkes (2002), DEFRA/Environment Agency (2005) explains the method of joint probabilities applied to the field of coastal engineering. The wave propagation is modelled in our study by the Goda analytical formula (2000) and the overtoppings are given by the TAW formulae (2002).

The propagation of offshore wave heights to the coast that is done by the Goda analytical formula on a regular bottom slope distinguishes two zones: the shoaling zone where the wave height increases slightly when the water depth decreases; and on the other hand the breaking zone where the wave height quickly decreases when the water depth decreases. Figure 3 presents the effect of MSL rise on the wave height in the front of the work. MSL rise can be represented as a movement of the coastal structures offshore. Consequently the works that are presently in shoaling zone will not see significant changes of wave heights. The works

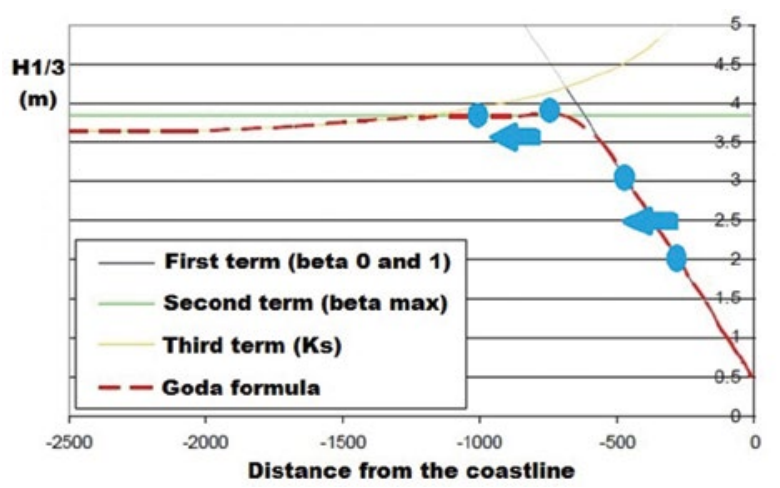

Figure 3 : Wave propagation with Goda analytical formula (2000) $-H_{0}^{\prime}=4 \mathrm{~m}, L_{0}=160 \mathrm{~m}$ and $m=1 \%$. 
that are presently in breaking zone i.e. in shallow waters will be subjected to stronger wave heights. The joint probability method is illustrated by figure 4. The latter figure presents two families of curves: the curves of iso-probability of an event at high tide in the axes (offshore wave height, sea level) on the one hand and the curves of iso-overtopping discharges in the same axes on the other hand. These latter curves are obtained using the Goda analytical formula (2000) for wave propagation and TAW formulae (2002) for overtopping. The interest of this presentation is to distinguish the probabilities of the event (joint exceedance probability of offshore wave height and sea level) from the probability of the impact (for example an overtopping discharge) that is calculated here by the relative number of events giving overtopping discharges superior to a given discharge (the events are presented by stars in figure 4). Figure 4 shows that these events divide up in two groups: in the breaking zone (large wave height) and in the shoaling zone (high sea level at high tide). In figure 4, among all the events with a return period of 5 years, the event giving the strongest overtopping discharge $\left(5.10^{-2} \mathrm{~m}^{3} / \mathrm{s} / \mathrm{ml}\right)$ is found at the border between breaking zone and shoaling zone. Considering climate change, MSL rise consists in moving the cloud of points rightward, the increase of the wave heights consists in moving it upward and the increase of the frequency of the storms in generating additional stars.

\section{REINFORCEMENT OF COASTAL WORKS}

We recall the strategies of adaptation proposed to the stakeholders : a) repairing the structures as they are b) reinforcing them c) demolishing and redesigning them d) accepting coastal realignment. Updating of design of the structure is a costly option. The stakeholder would often content himself with the strengthening (or reinforcement) i.e. the strategy $b$. The reinforcement has been studied on three types of structures with laboratory tests in wave flumes.

\section{IV.1. Maritime rubble mound breakwater}

Tests A are done in the wave flume of University of Le Havre in order to characterize several options of reinforcement for a maritime rubble mound breakwater.

For a $1 \mathrm{~m}$ MSL rise, among all the envisaged options, only the strengthening of the structure by a third layer of

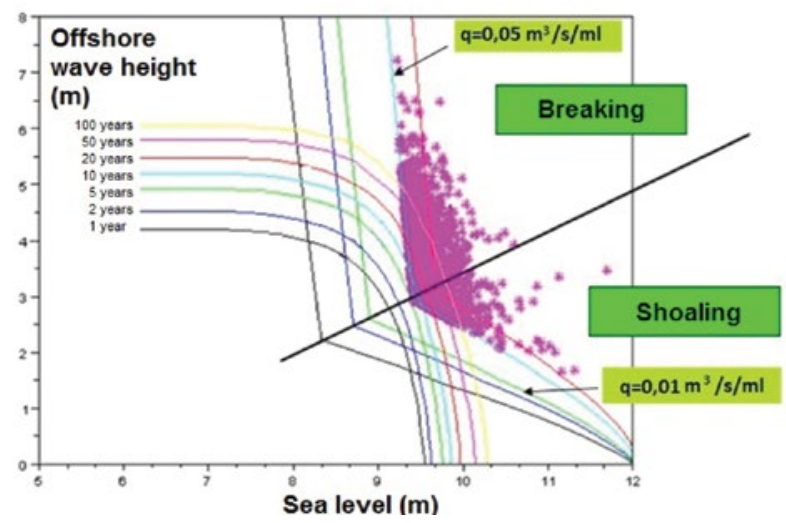

Figure 4 : Curves of iso-probability of an event and of iso-overtopping discharge for the Deauville breakwater.
Antifer armour units and a raise of the crown wall up to the level of the superior berm enable to reduce the overtopping discharges down to their initial values (without MSL rise). With the armour units of the same dimension for the third layer as the ones of two initial armour layers, the armour stability is largely improved in comparison with the initial conditions.

\section{IV.2. Maritime impervious breakwater}

Tests B are performed in the wave flume of Laboratoire National d'Hydraulique et Environnement (LNHE-EDF) in order to study in laboratory the different options of reinforcement of maritime impervious breakwaters that enable to keep the same overtopping discharge with $1 \mathrm{~m}$ MSL rise. The most promising options are the $1 \mathrm{~m}$ high curved parapet wall (cf. figure 6a) and the front reservoir (cf. figure 6b) with orifices for evacuation of overtopping volumes. These options of reinforcement with $1 \mathrm{~m}$ MSL rise allow us to keep or to reduce the overtopping discharge that is observed with the present MSL without reinforcement. The front reservoir consists in creating in front of the breakwater a seafront walk that is protected by a porous parapet with rectangular openings.

The addition of armour units on the impervious slope is not an adapted option of reinforcement (even if it can reduce the overtopping discharge in the preliminary tests) because this armour layer is unstable despite the armour size used in the laboratory test i.e. 4-6 T.

\section{IV.3. Rubble mound breakwater positioned on the upper beach}

Tests $\mathrm{C}$ are done in the wave flume of LNHE-EDF in order to study in laboratory the different options of reinforcement of rubble mound breakwaters positioned on the upper beach that enable to keep the same overtopping discharge as well as the same armour stability with $1 \mathrm{~m}$ MSL rise. Among the tested options, the best results are obtained with the following reinforcements : 1) third layer with 5-6 $\mathrm{T}$ armour units and a $2 \mathrm{~m}$ raise of crown wall (cf. figure 7a) 2) a smoother slope of armour layer (1:3 slope instead of 1:2 slope) and a $1 \mathrm{~m}$ raise if crown wall (cf. figure $7 \mathrm{~b}$ ). The raise of the crown wall must always be combined with a reinforcement of the armour layer because it is observed that the armour layer is unstable when the crown wall is raised with $1 \mathrm{~m}$ MSL rise.

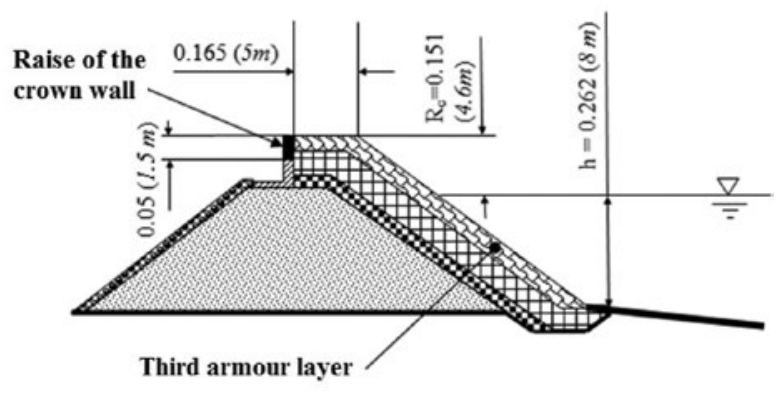

Figure 5 : Advised reinforcement for a maritime rubble mound breakwater. 

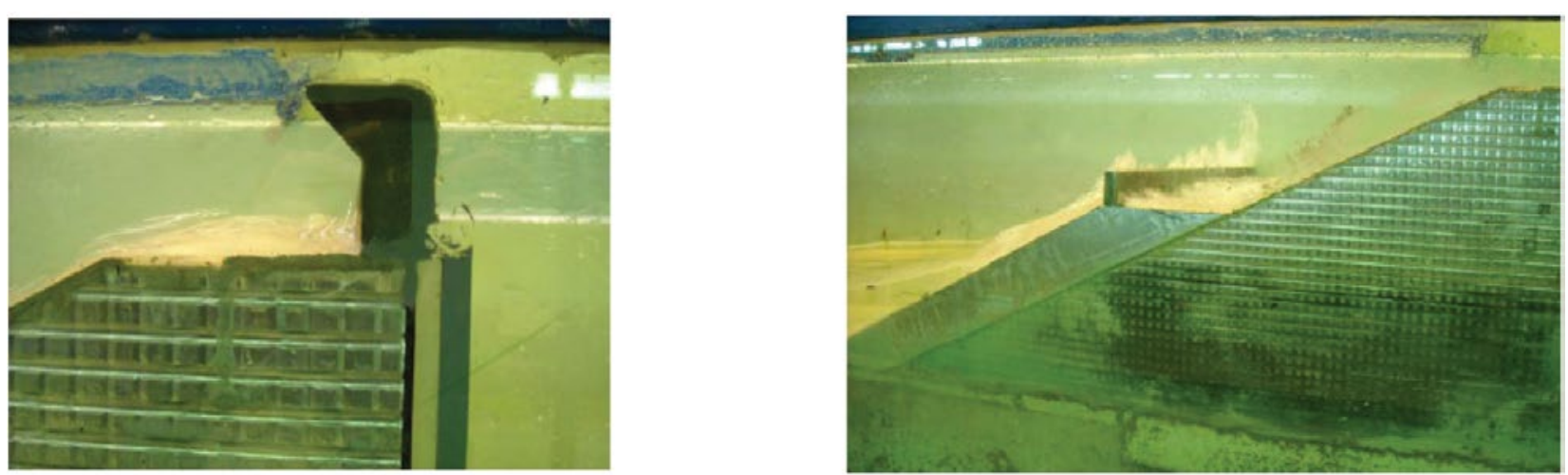

Figure 6 : Curved parapet wall $(a-l e f t)$ and front reservoir $(b-r i g h t)$.
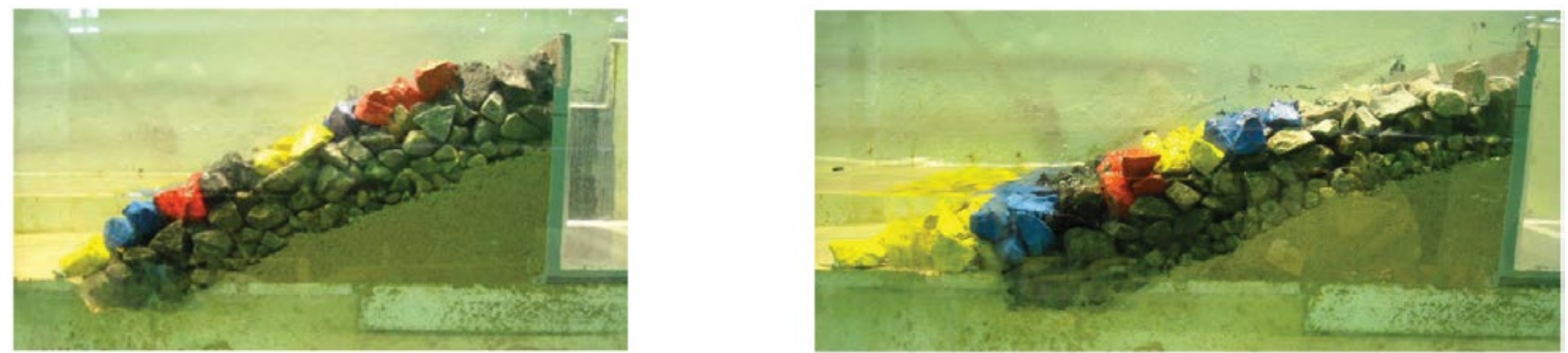

Figure 7 : Third layer with 5-6 T armour units and a $2 \mathrm{~m}$ raise of crown wall (a-left) and smoother slope of armour layer (1:3 slope instead of 1:2 slope) and a $1 \mathrm{~m}$ raise if crown wall $(b-$ right $)$.

\section{SELECTION OF THE DEFENCE STRATEGY IN DISTRICT OF MALRAUX}

\section{V.1. Sites of the city of Le Havre}

The city of Le Havre is crossed from East to West by a dead cliff which marks the old border between the high city and the low city. The low city is thus developed in the old intertidal space where the sea level evolves between high tide and low tide. To analyze the risk of marine flood in a thorough way, we choose three sites corresponding to different configurations in terms of flood (overflowing versus overtopping) but also in terms of protection and potential scenarios of adaptation. Districts Centre and Saint François are protected from the water waves by the breakwaters of the port and by small low walls around the basins. They are the lowest districts and the first ones subjected to a flood by overflowing at high tide like the floods, which already occurred in the past in the district Saint François. Then the littoral space of the Northwest zone is constituted by the municipality of Sainte-Adresse and by the beach of Le Havre. This zone is protected by a low defence wall down from Sainte-Adresse up to the South of the beach on more than 1500 meters and by a work in pebble in the South of the marina on more than 800 meters.

The district of Malraux is protected by a rubble mound breakwater that is surmounted itself by a low wall. It is one of the most interesting sites for our study because the work subjected to the waves can undergo damage during the extreme events. We calculate, for various MSL rise, the total overtopping or overflowing volume which is going to flood the city during an extreme event (high tide + storm) that is estimated in Le Havre at approximately 2 hours. For that purpose, the average discharge is calculated at first (by $1 \mathrm{~m}$ ) on a section of the parapet wall then multiplied by the length of the section and then by the duration of 2 hours to obtain a volume added on the length of the work. We wish to know the flood map corresponding to this volume of water in the considered zone. The latter is modelled as a basin. The maximal inland limits of the basin that is filled by the sea are defined. The flood in the district of Malraux is wide because of the relatively low topography.

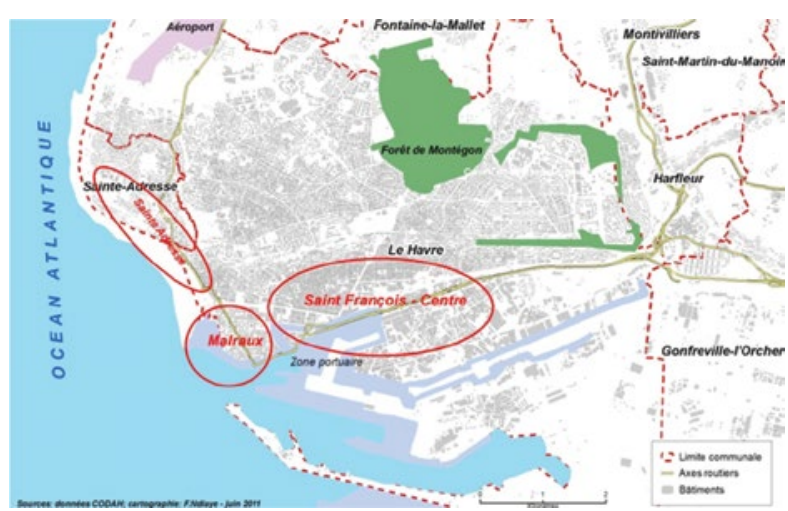

Figure 8 : Sites of the city of Le Havre. 


\section{V.2. The flood data in Le Havre}

The geographical configuration of the three sites such as explained above shows that in these zones a marine flood occurs in different ways. In Saint François, a marine flood fills the basins which in turn overflow the city. In Sainte-Adresse or in Malraux, the direct interface with the sea establishes a different dynamics in case of marine flood. There is overtopping or overflowing on the low parapet walls.

However, with overflowing of basins or with overtopping on low parapet walls, the physical parameters used for the calculation of the damage on the stakes in the territory are the same: - Upstream, the boundary conditions are essentially given by the tide and wind set-up (the addition of the two latter ones constitute the marine level) and by the wave height.

- Downstream, that is an inland territory, we are interested in the "hydraulic" state of the flooded zones. The flood maps are deducted or calculated from the knowledge of the upstream conditions, the topography and the physics of the flow.

On this second point, three parameters that ideally we would like to know completely on the territory are: the water height, the duration of flood and the current velocity. However it is difficult to know them in a precise way without the help of a 2D hydraulic model (all the more in urban zones), and that is why the majority of the studies of the floods is based only on the maximal water depth to set up scenarios and calculations of simplified damage.

Concerning the sea level, Le Havre has tidal stations which register in a regular way the water levels for more than half a century. So, the reference document for the statistics of extreme levels developed from a partnership between the CETMEF and the SHOM, presents the maps of the extreme water levels at high tide for return periods of 10 , 20, 50 and 100 years [Simon, 2008]. Therefore according to this study, the centennial flood in Le Havre is 9.30 meters CMH (Cote Marine du Havre).

\section{V.3. Damage to the breakwater of Malraux}

In the absence of information on the characteristics of the breakwater of Malraux, we made the hypothesis that the work was presently stable when it is subjected to a centennial wave. The work is not directly submitted to the offshore wave in the outer harbour. An abacus of diffraction was thus used to determine the incident waves on the work. The work is supposed to consist of 1-3 $\mathrm{T}$ armour units. The statistical method for damage estimations is the same as that used for the overtopping case. From the database of 10000 years, the sea conditions are propagated up to the coast: the wave heights are thus known at the entry of the port, the diffraction coefficient

Table 3: Stability coefficient Kd versus the return period and MSL rise.

\begin{tabular}{|c|c|c|c|c|c|c|}
\hline Kd & $\begin{array}{c}\text { Return } \\
\text { period (years) }\end{array}$ & 1000 & 500 & 333 & 250 & 200 \\
\hline \multirow{5}{*}{$\begin{array}{c}\text { MSL } \\
\text { rise } \\
(\mathrm{m})\end{array}$} & 0 & 4 & 4 & 4 & 4 & 4 \\
\hline & 0.5 & 5 & 5 & 4 & 4 & 4 \\
\hline & 1 & 6 & 5 & 5 & 5 & 5 \\
\hline & 1.5 & 6 & 6 & 6 & 6 & 6 \\
\hline & 2 & 7 & 7 & 7 & 7 & 7 \\
\hline
\end{tabular}

is applied. The Hudson formula [Ciria Cur Cetmef, 2007] is finally used to analyze the breakwater stability. Thus the studied criterion is not any more the overtopping discharge, but the damage through the stability coefficient $\mathrm{Kd}$. The obtained results are extreme damages. A statistical analysis enables to determine the return period of the damage (cf. tables 3 and 4).

Four levels of damages of armour layers are retained in reference to the main guides of conception: the beginning of damage, the intermediate damage, the important damage, and the breaking. Each of these levels corresponds to a stability coefficient, which can be related to a percentage of moved armour units.For the strategy of "doing nothing", we can reasonably think that the contracting authority will realize works according to the various levels of damage.

- In the beginning of damage, no program of works is envisaged;

- In the intermediate damage, the contracting authority starts a program of works that consists in putting back in place the missing armour units;

- In the important damage, the contracting authority starts a general confortement of the armour layer;

- In the breaking, the work is replaced by an identical work.

The maintenance costs supported by the contracting authority are given in the table 4 . For the strategy of strengthening, the cost estimates of reinforcement (in $€$ 2012) of the table 5 are retained.

The contracting authority, considering the costs and according to the results of laboratory tests will choose certainly the solutions $(1+3,1+5,2)$. We shall thus retain $7500 € \mathrm{TTC} / \mathrm{lm}$ as average cost of a strengthening. The armour stability is very affected by the scenarios of MSL rise. For a $2 \mathrm{~m} \mathrm{MSL}$ rise, only scenario presented here, each event with return period superior to 100 years leads to a damage level of breaking. The strategy is clearly to strengthen the work in position or to build a new work that resists (redesigning).

\section{V.4. Damage to goods}

The information collected on the average price of housing in $\mathrm{m}^{2}$ allows us to establish besides a list of the values for several types of buildings. This information enables to calculate the damage of buildings during overtopping or overflowing (cf. tables 6 and 7). The used method is as follows:

- An inventory of the stakes based on the approach by entities of goods [Givone, 2005] is adopted to characterize the majority of the vulnerable physical stakes in the floods, in particular the public and private buildings.

- The map of the floods is crossed with that of the stakes on the various zones to analyze the levels of risk from the water height in front of each stake.

- The following formula of the rate (or \%) of damage in the floor is chosen: $\mathrm{Ee}=5.68 \mathrm{H}+(16.45 \%)$ [Torterotot, 1993] where $H$ represents the water height.

- The economic cost of the damage is estimated according to the following formula: $\mathrm{CE}=\mathrm{Ee} \times \mathrm{Se} \times \mathrm{Cs}$ with $\mathrm{CE}=$ cost of the damage for a building, $\mathrm{Ee}=$ its rate of damage, $\mathrm{Se}=$ its surface on the ground and Cs: its cost by $\mathrm{m}^{2}$.

- The evaluation of the average price of housing by $\mathrm{m}^{2}$ enables to know the value of the properties concerned in monetary term (evaluation of $\mathrm{Cs}$ ).

- The final scenarios proposed for an economic study and a comparison of the strategies of adaptation according to the severity of the climate change are chronologically as follows: doing nothing (cost of the damage in the work + cost of the damage in the properties); strengthening (cost of the strengthening 
Table 4 : Correspondence between stability coefficient $K d$ and the damage level, the percentage of moved armour units and the maintenance costs (CETMEF's data).

\begin{tabular}{|c|c|c|c|}
\hline Kd & Damage level & Damage in \% & Maintenance costs (estimates) \\
\hline 4 & Beginning of damage & $0-5$ & $0 € \mathrm{HT} / \mathrm{lm}$ \\
\hline 5 & Intermediate damage & $5-10$ & $500 € \mathrm{HT} / \mathrm{lm}$ \\
\hline 6 & Important damage & $10-15$ & $2500 € \mathrm{HT} / \mathrm{lm}$ \\
\hline 7 & Breaking & $15-20$ & $30000 € \mathrm{HT} / \mathrm{lm}$ \\
\hline
\end{tabular}

Table 5 : Cost estimates of reinforcement (CETMEF's data).

\begin{tabular}{|c|c|c|}
\hline $\mathbf{N}^{\circ}$ & Reinforcement of structures & Cost estimates of reinforcement \\
\hline 1 & $50 \mathrm{~cm}$ high parapet wall & $1.5 \mathrm{k} € \mathrm{HT} / \mathrm{lm}$ \\
\hline 2 & Front reservoir & $7 \mathrm{k} € \mathrm{HT} / \mathrm{lm}$ \\
\hline 3 & Berm & $5 \mathrm{k} € \mathrm{HT} / \mathrm{lm}$ \\
\hline 4 & Detached breakwater & $25 \mathrm{k} € \mathrm{HT} / \mathrm{lm}$ \\
\hline 5 & Additional armour layer & $2.5 \mathrm{k} € \mathrm{HT} / \mathrm{lm}$ \\
\hline
\end{tabular}

+ cost of the damage in the work + cost of the damage in the properties); redesigning (cost of the reconstruction + cost of the damage in the work + cost of the damage in the properties); realignment (cost of the realignment + cost of damage in the properties). As regarding the realignment, a second line of defence can be created with costs of damage associated to it.

- The principle of the annualization of the costs is used to compare the strategies.

- The proposed economic study is not sufficient when the safety is involved. In a general way, other criteria of decision come into play: the indirect economic costs; the safety; the acceptability; the environment; etc. An approach with multi-criteria is thus sometimes necessary.

In table 7 , we find that the work has important damages until the return period of 100 years but the breaking for more severe events justifies much more important maintenance costs. In 1000 years, on average and approximately, several severe events will happen: 1 event of return period of 1000 years, 1 event of return period of 500 years, 1 event of return period of 333 years, etc. The total cost of damages in 1000 years is therefore the sum of the costs for each event divided by 1000 .

For building costs and costs of realignments, the choice is made to amortize the costs over 100 years.
Table 6 : Overtopping or overflowing volumes versus the return period and the MSL rise.

\begin{tabular}{|c|c|c|c|c|}
\hline Volume $\left(\mathbf{M m}^{3}\right)$ & $\begin{array}{c}\text { Return period } \\
\text { (years) }\end{array}$ & $\mathbf{1 0 0 0}$ & $\mathbf{5 0 0}$ & $\mathbf{3 3 3}$ \\
\hline \multirow{3}{*}{$\begin{array}{c}\text { MSL } \\
\text { rise } \\
(\mathrm{m})\end{array}$} & 0.5 & 12 & 3 & 1 \\
\cline { 2 - 5 } & 1 & 23 & 8 & 3 \\
\cline { 2 - 5 } & 1.5 & 34 & 23 & 11 \\
\cline { 2 - 5 } & 2 & 45 & 33 & 15 \\
\hline
\end{tabular}

\section{V.5. Comparison of strategies}

The contracting authority will adopt four different attitudes: - Doing nothing, which consists in reconstructing the work to the initial status and to bear the costs of damage to goods at the back of the dike;

- Strengthening the existing work with the help of, for example, a front reservoir, a berm or an additional armour layer with a crown wall, in order to give a stability and an overtopping discharge close to their value before MWL rise;

Table 7 : Costs for 2 m MSL rise.

\begin{tabular}{|c|c|c|c|c|c|c|c|c|c|c|c|c|c|c|c|}
\hline \multicolumn{2}{|c|}{ Return period } & \multirow{2}{*}{$\begin{array}{c}20 \\
0\end{array}$} & \multirow{2}{*}{$\begin{array}{r}40 \\
0\end{array}$} & \multirow{2}{*}{\begin{tabular}{|c|}
100 \\
0 \\
\end{tabular}} & \multirow{2}{*}{$\begin{array}{r}111 \\
0\end{array}$} & \multirow{2}{*}{$\begin{array}{c}125 \\
0\end{array}$} & \multirow{2}{*}{$\begin{array}{c}143 \\
0\end{array}$} & \multirow{2}{*}{\begin{tabular}{|c|}
167 \\
0 \\
\end{tabular}} & \multirow{2}{*}{\begin{tabular}{|c|}
200 \\
0 \\
\end{tabular}} & \multirow{2}{*}{$\begin{array}{c}250 \\
0\end{array}$} & \multirow{2}{*}{$\begin{array}{r}\mathbf{3 3 3} \\
7,7\end{array}$} & \multirow{2}{*}{$\begin{array}{r}\mathbf{5 0 0} \\
15\end{array}$} & \multirow{2}{*}{\begin{tabular}{|r|}
1000 \\
27 \\
\end{tabular}} & \multirow{2}{*}{$\begin{array}{c}\begin{array}{c}\text { Annual } \\
\text { cost }\end{array} \\
\text { in } \mathbf{M} € \\
0.050\end{array}$} & \multirow{3}{*}{$\begin{array}{c}\begin{array}{c}\text { Total } \\
\text { cost }\end{array} \\
\text { in } \mathbf{M €}\end{array}$} \\
\hline \multirow{2}{*}{ Doing nothing } & Damage to goods & & & & & & & & & & & & & & \\
\hline & Damage to work & 2 & 2 & 2 & 24 & 24 & 24 & 24 & 24 & 24 & 24 & 24 & 24 & 0.222 & \\
\hline \multirow{2}{*}{ Strengthening } & Damage to goods & 0 & 0 & 0 & 0 & 0 & 0 & 0 & 0 & 0 & 0,1 & 0,1 & 3,1 & 0.003 & \multirow{2}{*}{0.063} \\
\hline & Building costs & \multicolumn{12}{|c|}{ Cost of strengthening $6 \mathrm{ME}$} & 0.060 & \\
\hline Redesigning & Building costs & \multicolumn{12}{|c|}{ Cost of redesigning $24 \mathrm{M \epsilon}$} & 0.240 & 0.240 \\
\hline Realignment & Cost of realignment & \multicolumn{12}{|c|}{ Cost of realignment $508 \mathrm{M \epsilon}$} & 5.080 & 5.080 \\
\hline
\end{tabular}


- Deleting the existing work and building a new one adapted to the new MWL. This measure will be designed to have almost no damage and limited overtopping volumes. The cost is estimated at $30 \mathrm{k} € \mathrm{TTC} / \mathrm{ml}$ and no damage to goods due to the overtopping or overflowing is possible ;

- Realigning by leaving the area behind the work (chosen here as the flooded area for a millennial event).

\section{CONCLUSIONS AND PERSPECTIVES}

In the district of Malraux, the strategy of strengthening becomes more interesting economically than the strategy of "doing nothing" from a $1 \mathrm{~m}$ MWL rise and remaining the most economic solution up to $2 \mathrm{~m}$ MWL rise. The strategy of realignment must be envisaged only locally because of its relatively high cost. The project highlighted the interest to get a database of the joint probability for wave heights - water levels along the French coast. A method was developed to select the most economic solution of strengthening a work. This method must be implemented in an IT tool to propose an expert system to the contracting authorities. The laboratory tests led within the framework of the project to determine in a qualitative way the most promising solutions of strengthening. But new design formulae (as regard in particular the armour stability, the crown wall stability or the overtopping volumes) are still to be obtained in order to highlight the significant interaction between strengthening of the superstructures and stability and, inversely, between strengthening of the armour layers and overtopping. These problems are still little studied in the literature. It should finally be recalled that the danger is situated in several scales: the scale of the work, the scale of the zone directly protected by the work, the scale of the zone impacted by the flood risk.

\section{ACKNOWLEDGMENTS}

This work has been partially funded by the SAO POLO projet of program Gestion et Impact du Changement Climatique (GICC) and by the THESEUS project of the 7th European Framework.

\section{REFERENCES}

Ciria, Cur, Cetmef (2007) - Rock Manual

Defra (2005) - Use of Joint Probability Methods in Flood Management A Guide to Best Practice. R\&D Technical Report FD2308/TR2 - DEFRA/Environment Agency

Givone P. (2005) - Détermination des risques d'inondation : effets de l'aménagement de l'espace. Comptes Rendus Geosciences. 337(1-2) 229-241

GodA Y. (2000) - Random Seas and Design of Maritime Structures PL-F Liu (ed). Advanced Series on Ocean Engineering. World Scientific, Singapore. 15

HAWKes P.J. (2002) — The joint probability of waves and water levels in coastal engineering design. Journal of hydraulic research. 40(3) 241-251

Lebreton P., Trmal C. (2009) - Evaluation de l'impact du changement climatique sur le dimensionnement des digues à talus. La Houille blanche. 2 45-51

SERGENT P. (2012) - Stratégies d'adaptation des ouvrages de protection marine ou des modes d'occupation du littoral vis-à-vis de la montée du niveau des mers et des océans. Rapport GICC $N^{\circ}$ G.90006812 -SAO POLO. 119 p

Simon B. (2008) - Les niveaux marins extrêmes le long des côtes de France et leur évolution. Rapport

TAW (2002) - Technisch rapport golfoploop en golfoverslag bij dijken (Technical report on wave run-up and wave overtopping at dikes in Dutch). Technical Advisory Committee on Water Defences, Delft

TORTEROTOT J.P. (1993) — Le coût des dommages dus aux inondations. Estimation et analyse des incertitudes.Thèse de doctorat, ENPC 